\title{
СОЦІАЛЬНІ РУХИ ЯК ЦЕНТРАЛЬНА КАТЕГОРІЯ АНАЛІЗУ СУЧАСНИХ СУСПІЛЬСТВ
}

\section{Т.В. Кушерець}

Будучи вихованими у західній культурній традиції, ми почуваємося упевненими, коли за відправну точку теоретичного аналізу беремо індивідуальну особистість. Найбільш індивідуалістична традиція укорінилася у психології та економіці, де базовою одиницею аналізу є індивід, а перехід до вищих рівнів організації часто зводиться до поєднання індивідів. Але і в соціологічних дослідженнях підсумовують і визначають відсоткове відношення індивідуальних відповідей на оглядові запитання і стверджують, що визначили «громадську думку». Навіть Г. Зіммель у одному із своїх визначень суспільства загравав із аналогічним твердженням. Суспільство, писав він, $є$ «лише назвою для суми (соціальних) взаємодій. $\langle\ldots>$ Тому воно не $\epsilon$ уніфікованим фiксованим поняттям, а радше витворюваним ... сузір'ям індивідів» $[2$, c. 317].

Якщо, використовуючи такий підхід, спробувати пояснити, чому люди приєднуються до тих чи інших соціальних рухів, то пошук відповідей приведе до витворення багатьох «причин для приєднання»наслідування, шкідливий вплив, сугестивність, ідеологічні зобов'язання, емоційне задоволення тощо. Якщо ми підійдемо до вирішення цієї проблеми у межах індивідуально-утилітарної традиції, то взагалі не знайдемо вагомих причин, які спонукали б індивідів приєднуватися до соціальних рухів: аналіз витрат і прибутків не дає ніякого релевантного мотиву для участі.

Корисно пригадати деякі особливості історії вивчення соціальних рухів. Хоча Маркс і Токвіль визначали революційні рухи як невід'ємну частину конвульсивних історичних змін, по справжньому соціаль-

Актуальні проблеми духовності 
на психологія і соціологія соціальних рухів почалася з праць Гюстава Лебона, французького журналіста, наприкінці XIX сторіччя. Аналіз рухів цим мислителем був найвищою мірою ірраціоналістичним, він трактував натовпи як нерозумні, імпульсивні, емоційні, схильні до сугестії та демагогії, як такі, що руйнують самоконтроль індивідів і здатні до деструктивності й ідеалізму в крайніх формах. Більш того, він ненавидів натовп як такий, що руйнує інститущії, і приписував появу «ери натовпів» патології, вивільненій занепадом традиційних феодальних та релігійних інституцій. Точка зору Лебона на соціальні рухи домінувала у наукових колах протягом кількох десятиліть, зумовивши значну підтримку психологічних теорій З. Фрейда, В. МакДугласа та соціологічної концепції Е.А. Росса.

Починаючи з середини XX сторіччя, така негативна оцінка колективної поведінки була пом'якшена, оскільки ці явища стали об'єктом того, що можна назвати «натуралістичним дослідженням». Саме серед таких дослідників і був Г. Блумер, який на основі узагальнення досвіду відомих «старих рухів», зокрема більшовицького та нацистського, виявив загальні для таких рухів механізми розвитку - агітацію, формування корпоративного духу, розвиток нової моралі, ідеологію та тактику. Застосування виявлених закономірностей до аналізу якісно «нових рухів» не допомагало розкрити специфіку останніх, тим більше що на момент написання роботи «Колективна поведінка» (1951) ці рухи ще не стали масовими. Блумер назвав ці принципово нові феномени «загальними соціальними рухами», вказуючи, що їх основою стали послідовні та глибокі зміни людських цінностей. «Загальні соціальні рухи набувають форми намацування (groping) та некоординованих спроб. $\mathrm{y}$ них є лише деякий загальний напрямок, у якому вони просуваються повільно, спотикаючись, але наполегливо» [1, с. 196].

$\mathrm{У}$ найновітніших дослідженнях соціальних рухів кінця XX століття стали переважати дві лінії аналізу. Першою $€$ «теорія мобілізації ресурсів», що викристалізувалася у роботах М. Залда, Р. Еша, В. Гемсона. У відповідності з їх головним змістом, соціальні рухи не слід пояснювати залученням маргіналів та невдоволених у лави прихильників ірраціональних ідеологій. Навпаки, соціальні рухи краще розглядати як цілеспрямовані, скеровані заходи, успіх або невдача яких залежить від їхньої ефективності в мобілізації ресурсів, будь то фінансова підтримка чи визнання політичними партіями. Під мобілізацією прихильники такої школи розуміють «процеси, за допомогою яких невдоволена група збирає ресурси і використовує їх для досягнення групових цілей» [5, с. 354]. У такому процесі особливу роль відіграють ті, хто мобілізує 
людей, або «підприємці руху», організатори та лідери, які іноді стають професіоналами. Прихильників «теорії мобілізації ресурсів» сьогодні критикують за применшення ідеологічних, соціально-психологічних та культурних аспектів рухів.

Друга лінія аналізу представлена концепцією «нових соціальних рухів» А.Турена. Його відправною точкою було визнання того, що старі соціальні рухи - рух за об'єднання робітничого класу та революційні рухи, які розуміються в контексті марксистського світогляду, - були в основному вичерпані, так само як і марксистський аналіз. «Нові» соціальні рухи не мали, зокрема, класової основи. Серед них були регіональні, расово-етнічні та мовні, антивоєнні та антиядерні, феміністичний та рухи на захист контркультури і певного стилю життя. Проте більшість їхніх інтерпретаторів зберігали неомарксистську та неокритичну ноту у своїх поясненнях, оскільки тлумачили ці рухи як своєрідний узагальнений протест проти гнітючого «капіталістичнодержавно-бюрократично-технологічно-медіа» комплексу в сучасному суспільстві.

Цей короткий огляд історії вивчення соціальних рухів показує, що проблема наділення мотивами, причинами та розумінням людей і організацій є періодично повторюваною методологічною проблемою. Лебон i ті, на кого він вплинув, вирішували цю проблему безпосередньо, наділяючи учасників суспільних рухів ірраціональністю, а то й психічним розладом. Тi, хто виділяють відчужених та маргіналів як кандидатів для соціальних рухів, також мають «теорію» щодо того, чому певні соціальні обставини роблять індивідів схильними піддаватися ідеологіям соціальних рухів. Навіть теоретики мобілізації ресурсів, які схильні вважати мотивацію вторинною, не могли уникнути питання про те, чому люди готові бути мобілізованими.

Є підстави вважати, що зростання масштабу та масовості соціальних рухів пов'язане із втратою національним суспільством своїх позицій як добре збалансованого цілого, як основної точки відліку в організації соціального життя та основної аналітичної одиниці. Поняття суспільства стає відкритим для обговорення і як емпірична реальність, і як головна організуюча складова у суспільних науках. Одним із чинників, що підштовхує до дискусіі, стала зростаюча значущість багатоманітності сучасних суспільств.

Соцільні основи багатоманітності $є$ історично змінними. Тривалі періоди західної історії були позначені релігійною багатоманітністю, хоча вона й пішла на спад від часу зростання індустріалізації та формування національних держав. Однак не слід забувати про залишкову 
релігійну основу деяких європейських політичних партій та про тривкий і надзвичайно глибокий вплив релігії у таких регіонах як Північна Ірландія, Іспанія, колишня Югославія та інші Балканські території, так само як і про фундаменталістські рухи повсюди.

До виникнення національних держав місцевість та місцева культура служили головною основою соціальної взаємодії та ідентифікації. Ця основа змогла протистояти інституційним і часом свідомим політичним зусиллям ринку й національної держави витіснити іiі, а в минулому десятиріччі місцевий патріотизм - виражений у вигляді вимог автономії, чистоти та визнання - знову утвердився. Соціальні основи расової етнічності, мови, гендеру, а також сексуальних приорітетів та, до певної міри, вікового цензу вийшли на перший план як важливі чинники групової ідентичності та основи для формування соціальних рухів.

У багатьох регіонах світу культурна багатоманітність з'явилася внаслідок міжнародного та міжнаціонального переміщення народів. Останнє, в свою чергу, стало результатом змін у вимогах роботи, війн та інших політичних криз, які породили мігруюче населення, та активізації туризму. Схоже, немає причин не вірити, що такі рухи зростатимуть.

Національним державам важко впоратися із зростаючою культурною багатоманітністю, важко дати раду з політичними групами та соціальними рухами, які виставляють свої вимоги щодо культурних понять. Фактично, існують свідчення того, що держави часто об'єднують зусилля в безуспішних спробах применшити політичне значення таких категорій, як раса, етнічність, гендер та сексуальні приорітети.

Об'єднавчий наслідок інтернаціоналізації економіки та розвитку регіональних політичних альянсів, таких як Європейський Союз, без сумніву дав можливість субнаціональним, регіональним, етнічним та мовним рухам вимагати у своїх програмах політичної лояльності. Парадоксальним чином, у міру того, як ці соціальні рухи набрали сили i законності, вони ставали активними чинниками в послабленні держави-нації як об'єкта лояльності та осереддя культурної ідентичності.

Н. Смелзер висунув припущення, що тенденція до локалізації $є$, фактично, «протестом проти зростання масштабів світових ринків та глобальної політики, можливо навіть є свого роду підтвердженням обмежень для людських зв'язків, які не можуть до кінця розширюватись у масштабах плинності та багатоманітності. $<\ldots>$ Буде цілком слушно інтерпретувати нове утвердження локалізму та місцевої автономії як зусилля з боку людських груп допомогти контролю у світі, який, як 
видається, стає дедалі неконтрольованішим» [3, с. 80].

Зростаюча багатоманітність та соціальні рухи, що виникають на іiї основі? створюють особливі труднощі для інтеграції суспільства політичним шляхом. 3 часів Дюркгейма соціальна інтеграція (солідарність) стала розглядатися як явище постійно проблематичне та нетривке, що вимагає активних зусиль з боку чинників інтеграції, щоб відтворювати й підтримувати її серед громадян нації. Сучасні дослідники дійшли до висновку, що існує не один головний тип солідарності (органічна солідарність) у складних суспільствах, а радше багато типів, і що вони пов'язані один з одним і накладаються один на одного.

По-перше, це економічна інтеграція, або взаємозалежність спеціалізованих економічних чинників, зумовлена ринком. По-друге, це політико-правова інтеграція, яка передбачає роль уряду у підтриманні суспільного устрою шляхом регулювання поведінки та вирішення конфліктів. По-третє, культурна інтеграція (включаючи релігію, спільні цінності, спільну ідеологію та спільну мову). По-четверте, територіальна інтеграція, або об'єднання людей на підставі спільного місця проживання та сусідства.

Як уже зазначалося, більшість із цих аспектів інтеграції поєднані у сучасній державі-нації, а саме: національна економіка, національна територіальна суверенність, національна монополія на право, політичне регулювання на засоби насилля, національні цінності культури. Суттю сучасної держави $є$ те, що це поєднання на суспільному рівні не $є$ природним, і що ми фактично є свідками зростаючого роз'єднання, систематичного віддалення цих основ інтеграції одна від одної і від держави - i відповідно послаблення держави як інтегруючого інструменту. «Головна суперечність полягає в тому, що системи політико-правової і територіальної інтеграції на національній основі щораз більше блокуються економічними та політичними тенденціями переважним чином ,3-над“ і культурними тенденціями головно ,з-під“ рівня держави-нації» [3, с. 87].

Одна із основних проблем, що стосується керованості демократичних суспільств, має пряме відношення до феномену культурної багатоманітності. Вимоги, виставлені групами, сформованими на основі цінностей чи культури (часто первинними за характером), виявляються непростими для залагодження політиками саме тому, що мають схильність набувати абсолютного, безкомпромісного характеру. Ідея первинності передбачає насамперед те, що ці групи звичайно грунтуються на священних принципах членства та відданості цінностям. Визнаючи себе священними, первинними, вони мотивують свої позиції 
та вимоги асолютними принципами, безкомпромісними за характером. Поява таких груп та зародження на їх основі соціальних рухів призводять до нових типів конфліктів з невідомими раніше суб'єктами та способами вирішення.

Держава перестає втілювати принцип єдності суспільного життя. Ії̈ сприймають скоріше як «керівника підприємства», оскільки вона відіграє все важливішу економічну роль, як бюрократа або як тоталітарну владу. У той же час суспільне життя складається з мінливих форм поведінки, інтелектуальних дебатів, суспільних конфліктів. Ось чому національні почуття сьогодні значно слабші, особливо у Західній Європі, ніж півстоліття тому назад. Плоди культури стають все більше інтернаціональними, зростає кількість індивідів, які мандрують навколо світу, теж саме можна сказати і про ідеї та матеріальні блага, які переміщуються з усе більшою швидкістю. Паралельно з'являються різноманітні соціальні рухи, що заперечують будь-яку можливість для держави втручатися у суспільне життя. Все більше мислителів відстоюють ідею, що у високоіндустріалізованих суспільствах конфлікти та суперечки автономно досягають деякої єдності, зовсім не зобов'язаної ніякому зовнішньому принципу на зразок державного втручання.

Ідея суспільства отримує внаслідок цього новий смисл, який віднині менше визначається інститутами, центральною владою, цінностями або постійними правилами суспільної організації, ніж тією областю суперечок і конфліктів, котра має у якості глобальної мети суспільне використання символічних благ, що масово виробляються постіндустріальним суспільством.

На місце старих принципів єдності суспільства поступово приходить новий, котрий, на думку А.Турена, полягає у зростаючій здатності людських суспільств впливати на самих себе, тобто збільшувати дистанцію між виробництвом та відтворенням суспільного життя. Новим тут $є$ те, що єдність суспільного життя не походить більше із ідеї суспільства, а навпаки, суспільство розглядається тепер як сукупність правил, звичаїв, привілеїв, проти котрих спрямовані індивідуальні та колективні творчі зусилля. Метафізичні принципи єдності суспільного життя знаходять свою заміну у звершеннях людських дій, а висловлюючись більш широко, свободи.

Сучасні «складні» суспільства значно більше «виробляють», а значить менше «відтворюють»у порівнянні з «простими» суспільствами. У них не перестає розширюватися область суспільних відносин і конфліктів. Бачення суспільства як середовища зародження конфліктів починає «формуватися з того моменту, коли суспільство саме бере на 
себе відповідальніть за усю сукупність свого досвіду, замість того, щоб обмежувати область соціальної дії вузькою полосою, затиснутою між метасоціальним рівнем та структурами порядку в суспільстві», де дійовою особою майже завжди виступає держава [4, с.67]. Соціальні рухи вимагають права самим виступати носіями смислу, замість того, щоб виступати лише «служниками» партій, інтелектуалів або держави.

Нині поза межами еволюціонізму формується новий спосіб аналізу суспільств, котрі в результаті тривалого періоду зростання та криз, атомних загроз, тоталітаризмів та революцій, прийшли до переконання, що вони повинні пізнавати самих себе в якості продукта власної дії, а не як прояв людської природи, смислу історії або базового протиріччя. Уявлення про суспільство як систему поступилося уявленню про систему дії. Раніше в системі вбачали апарат відтворення та інтеграції, зараз - область конфліктів і змін.

А. Турен вирізняє три типи конфліктів, спрямованих на зміни одного або кількох важливих аспектів соціального та культурного устрою. Терміном колективна поведінка пропонує називати ті із конфліктних дій, котрі можуть бути проінтерпретовані як зусилля по захисту, реконструкції або адаптації деякого «хворого» елемента системи, чи мова йде про цінность, норму, владні стосунки або про саме суспільство. Якщо навпаки, конфлікти аналізуються як механізми модифікації рішень, а значить як фактори змін, як політичні сили в широкому смислі слова, Турен пропонує говорити про форми боротьби. Словосполучення соціальний рух рекомендується для позначення тих конфліктних дій, котрі прагнуть змінити відносини соціального панування, що стосуються характеру використання головних культурних ресурсів-виробництва, знання, норм моралі.

Соціальний рух не є відповіддю на суспільну ситуацію. Навпаки, ця остання є результатом конфлікту між соціальними рухами, що борються за контроль над культурними моделями. Такий конфлікт може привести до розпаду політичної системи або, навпаки, до інституціональних реформ, він постійно проявляється у формах соціальної та культурної організації, у владних відносинах. «Соціальний рух це конфліктна дія, за допомогою якої культурні орієнтації, поле історичності трансформуються у форми суспільної організації, визначені одночасно загальними культурними нормами та відносинами соціального панування» $[4$, с. 87$]$.

Поняття соціального руху споріднене з поняттям класу, але останній може бути цілком зведений до обставин, тоді як соціальний рух це дія суб'єкта, тобто людини, що ставить під запитання зведення істо- 
ричності до певної соціальної форми. У суспільних науках склалася започаткована К. Марксом традиція вивчення боротьби робітничого класу через аналіз капіталізму, його криз та кон'юнктури. Сьогодні назріла необхідність визначати класи у якості дійових осіб і розглядати їх не у зв'язку з протиріччями, а у зв'язку з конфліктами. Щоб підкреслити цю важливу зміну, Турен віддає перевагу поняттю соціальний рух, а не клас.

Поняття клас тісно пов'язане з антагонізмом, що мав місце у системі організації праці індустріального суспільства. За нових умов, коли владу захопили великі промислові, адміністративні, управлінські апарати, виникає конфлікт іншого типу. Віднині найсуттєвішою боротьбою $є$ боротьба не між капіталістами та робітниками на підприємствах, а між «апаратами і тими, хто їм служить, споживачами чи мешканцями». $\mathrm{Y}$ «програмованому суспільстві» ця боротьба виникає повсюдно, де існують управлінські апарати, які впливають на соціокультурну орієнтацію людей. Опір цій домінації не обмежується якоюсь частковою формою протесту, він набирає глобальної форми. Різноманітні масові рухи протесту (екологічні, феміністські, студентські, за демократичні права тощо) - це і $\epsilon$ нові форми боротьби, але не проти якогось певного класу, а проти системи «апаратів».

Виходячи з тези про анонімну силу технократії, яка маніпулює індивідуальним і суспільним життям, інтегрує та деформує його, французький мислитель вважає, що змінити цю ситуацію можна лише за умови переходу до нового способу життя, ідея якого обстоюється у нових соціальних рухах. На противагу примусовій регламентації поведінки людини в суспільстві починає виявлятися тенденція до пошуків особистої ідентифікації та причетності до спільноти.

\section{1 Бібліографія}

[1] Блумер Г. Коллективное поведение // Американская социологическая мысль: Тексты. - М., 1994.-- С. 169-215.

[2] Зиммель Г. Избранное. Том 2. Созерцание жизни. - М., 1996.

[3] Смелзер Н. Проблеми соціології. - Львів, 2003.

[4] Турен А. Возвращение человека действующего. - М., 1998.

[5] ШІтомпка П. Социология социальных изменений. - М., 1999. 